\title{
Pelatihan Pengolahan Data Statistik Dengan Aplikasi SPSS
}

\author{
Joni Wilson Sitopu ${ }^{1)}$ | Ika Rosenta Purba ${ }^{2)}$ | Tuahman Sipayung ${ }^{3)}$ \\ ${ }^{1,2)}$ Fakultas Keguruan dan Ilmu Pendidikan, Universitas Simalungun \\ ${ }^{3}$ Fakultas Ekonomi, Universitas Simalungun \\ jwsitopu@gmail.com
}

\begin{abstract}
Abstrak: Dalam aktivitas pengolahan data hasil penelitian diketahui bahwa masih banyak mahasiswa yang belum memahami program SPSS dalam mengolah data yang digunakan untuk menyusun tugas akhirnya. Hal tersebut dialami oleh mahasiswa Prodi Pendidikan Biologi FKIP Universitas Simalungun Pematangsiantar dimana masih banyak yang belum memahami cara pengoperasian program SPSS. Oleh karena itu perlu adanya pengenalan mengenai media pembelajaran berbasis teknologi yang terkait dengan program SPSS melalui pelatihan. Pelatihan ini merupakan bagian dari kegiatan pengabdian masyarakat yang bertujuan untuk memberikan tambahan ilmu pengetahuan, meningkatkan keterampilan, melatih pemikiran kreatif mahasiswa dan memudahkan dalam menentukan uji statistika yang digunakan dalam menyusun tugas akhir. Metode kegiatan pelatihan ini dibagi atas tiga bagian yaitu tutorial, workshop, dan simulasi. Setelah pelatihan selesai dilakukan, terlihat mahasiswa sangat antusias bahkan banyak diantara mereka mengajukan pertanyaan. Mahasiswa juga memberi apresiasi yang baik akan kegiatan pelatihan dan berharap diadakan lagi kegiatan yang berkaitan analisis data di waktu mendatang. Kegiatan pelatihan ini memberi nilai lebih bagi mahasiswa khususnya dalam menyelesaikan tugas akhir.
\end{abstract}

Kata Kunci: pelatihan SPSS, biologi, universitas simalungun

\section{Pendahuluan}

SPSS merupakan software aplikasi statistik yang populer bagi praktisi dan mahasiswa. Bagi para mahasiswa SPSS dapat membantu pengolahan data dan pengujian hipotesis untuk berbagai uji dan analisis dalam statistika, seperti uji t, uji F, uji-uji non parametrik, analisis regresi kolerasi, dan analisis multivariat dan lain-lain.

Dewasa ini, banyak peneliti dan praktisi yang bergerak di bidang pendidikan. Dalam pendidikan dibutuhkan perhitungan yang akurat mengenai pengolahan data dalam penelitian kuantitatif, karakteristik bidang pendidikan hingga mengenai perilaku mahasiswa hingga peneliti dewasa ini. Pada awalnya SPSS dibuat untuk keperluan pengolahan data statistik untuk ilmu-ilmu Social Sciens.

Program SPSS sering sekali digunakan untuk memecahkan suatu masalah riset atau bisnis dalam hal statistik. Sejalan dengan dibutuhkan metode statistik untuk melihat kecenderungan suatu fenomena, ada hal yang terkadang kurang tepat bagi peneliti dan praktisi, bila mana ada parameter yang sifatnya sangat kualitatif dalam mengambil kebijakan membutuhkan hasil yang kuantitatif. SPSS merupakan bagian integral dari tentang proses analisa, menyediakan akses data, persiapan dan manajemen data, analisa data dan pelaporan. SPSS salah satu perangkat lunak yang paling banyak dipakai karena tampilannya yang user friendly dan merupakan terobosan baru yang berkaitan dengan perkembangan teknologi informasi saat ini, khususnya dalam menjalankan suatu bisnis. Kemampuan SPSS diperluas untuk melayani berbagai jenis pengguna (user) seperti untuk proses produksi di pabrik, riset ilmu sains dan lainnya.

Jika pada mulanya SPSS dibuat untuk memecahkan masalah statistik pada ilmu sosial, maka dengan semakin populernya program ini maka sekarang aplikasi SPSS ini bisa digunakan di semua bidang. Saat ini banyak sekali perusahaan dan jutaan individu di dunia dalam berbagai bidang 
menggunakan Aplikasi SPSS dalam proses pengolahan data statistik, menjadikan SPSS program statistik yang paling laris dan populer di dunia.

Masalah yang dihadapi adalah masih banyak mahasiswa yang belum memahami program SPPS dalam mengolah data yang digunakan untuk menyusun tugas akhir mahasiswa. Perlu adanya pengenalan mengenai media pembelajaran berbasis teknologi yang terkait dengan program SPSS.

Perlu adanya workshop keterampilan bagi siswa dalam pemanfaatan media pembelajaran SPSS dalam pembelajaran statistika. Perlu adanya pelatihan penggunaan media pembelajaran media SPPS dalam menyelesaikan masalah statistik hingga dapat meningkatkan respon dan minat mahasiswa mengikuti pembelajaran statistika.

Dalam masalah yang dihadapi adanya adanya solusi yang dilakukan adalah dengan cara melakukan pelatihan bagi mahasiswa baik secara langsung mau secara daring menggunakan media secara online. Adanya solusi yang diberikan maka mahasiswa dapat memahami aplikasi SPSS dengan baik serta dapat membantu mahasiswa dalam menyelesaikan tugas akhir.

Dalam menghadapi masalah maka kita dapat menyelasaikannya, hasil yang diharapkan adalah dengan adanya pelatihan aplikasi SPSS yang dilakukan untuk mahasiswa yaitu mahasiswa menambah pengetahuan mahasiswa serta dapat membantu mahasiswa dalam mengolah data dalam menyelesaikan tugas akhir.

\section{Realisasi Kegiatan}

Persoalan yang dihadapi mahasiswa adalah kesusahan dalam mengolah data mentah hasil penelitian, hal ini menyebabkan diperlukan solusi yang konkret dan relevan terhadap kemajuan teknologi, oleh karena itu solusi yang ditawarkan dalam pengabdian ini adalah mahasiswa akan mampu mengelola data sesuai hipotesis dan melakukan uji validasi serta uji rehabilitas dalam waktu yang relative singkat, efisien meskipun yang dihadapi data yang tidak sedikit.

Dalam pelatihan dan sosialisasi tentang Aplikasi SPSS, terdapat tiga jenis kegiatan yang akan dilakukan yaitu tutorial, workshop, dan simulasi. Adapun rincian kegiatan secara garis besar yaitu:

\begin{tabular}{|c|l|}
\hline Kegiatan & \multicolumn{1}{|c|}{ Dekarya Ilmiah } \\
\hline \multirow{2}{*}{ Tutorial } & $\begin{array}{l}\text { Menjelaskan tentang Hipotesis sesuai dengan desaian penelitian, } \\
\text { Pengolahan Data, Uji Hipotesis, dan Validasi serta uji Realibitas. } \\
\text { Menjelaskan tentang sofware SPPS for windows melalui komputer. }\end{array}$ \\
\hline Workshop & $\begin{array}{l}\text { Pembimbingan dalam Pengolahan data, Uji Validitas, dan Realibilitas } \\
\text { dan Uji Hipotesis sesuai dengan desaian Penelitian. }\end{array}$ \\
\hline Simulasi & $\begin{array}{l}\text { Peserta mempraktekkan hasil pengolahan data, uji normalitas, uji } \\
\text { homogenitas, analisis regresi linier berganda, uji t, uji } \mathrm{R}^{2} \text {, uji } \mathrm{F} .\end{array}$ \\
\hline
\end{tabular}

Pelaksanaan kegiatan tutorial dipandu oleh pelatih 1. Sebagai wujud dari pelaksanaan dari kegiatan tutorial dapat dilihat pada gambar berikut :

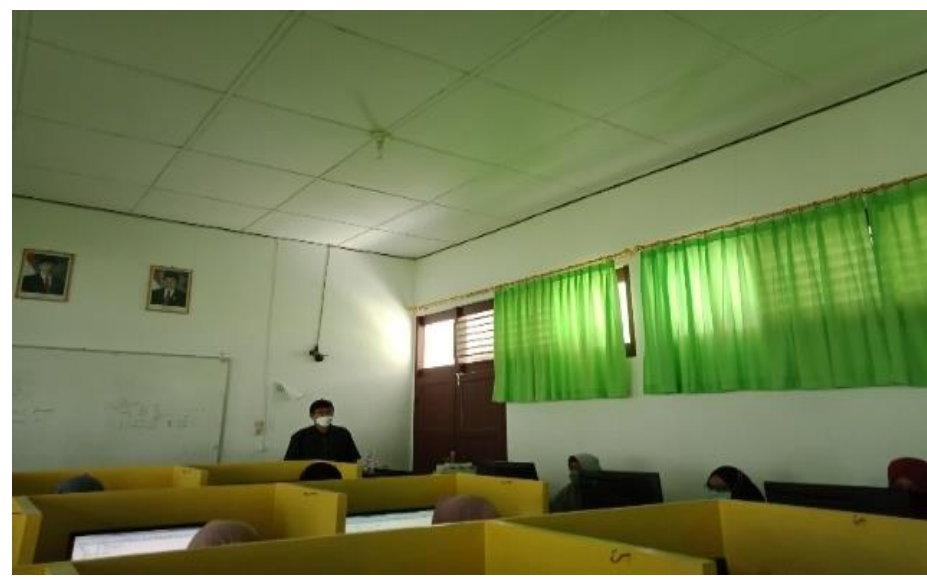




\section{Gambar 1. Tutorial}

Setelah dilakukannya kegiatan tutorial maka dilanjutkan dengan kegiatan workshop. Pelaksanaan tersebut dilatih oleh pelatih 2 . Adapun bukti pelaksanaannya dapat dilihat pada gambar berikut :

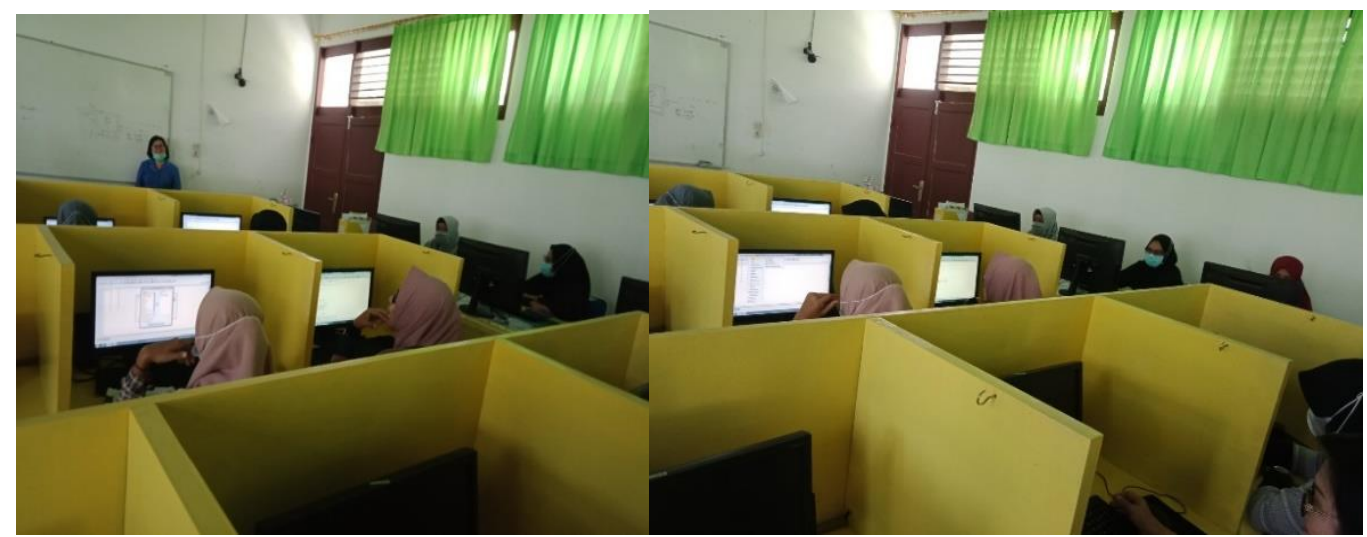

Gambar 2. Workshop

Setelah kedua kegiatan tersebut selesai dilaksanakan maka diadakanlah kegiatan simulasi terhadap para peserta pelatihan. Bukti pelaksanaan simulasi dapat dilihat pada gambar berikut :

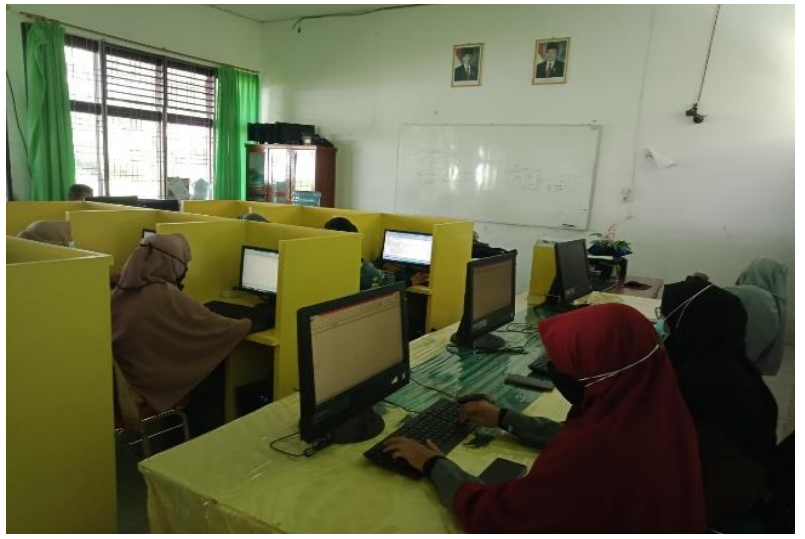

Gambar 3. Simulasi

\section{Hasil}

Hasil pelatihan aplikasi SPSS yang dilaksanakan adalah untuk menambah pengetahuan mahasiswa serta dapat membantu mahasiswa dalam mengolah data penelitian untuk menyelesaikan tugas akhir mahasiswa Fakultas Keguruan dan Ilmu Pendidikan Program Studi Pendidikan Biologi adalah sebagai berikut:

1. Mahasiswa Program Studi Biologi sangat antusias dengan adanya pelatihan ini, dan sangat banyak mahasiswa yang mengajukan pertanyaan seputar kegunaan analisis data yang digunakan dan tujuannya dengan penelitian yang akan dibuatnya sesuai konsentrasi di Program Studi Pendidikan Biologi.

2. Mahasiswa Program Studi Pendidikan Biologi mengapresiasikan kegiatan ini dan berharap ada kegiatan ini di masa mendatang untuk mengasah kemampuan mereka lebih dalam seputar alat analisis data.

3. Mahasiswa Program Studi Pendidikan Biologi membawa kasus penelitian terdahulu yang mereka siapkan sebelum pelatihan untuk dipertanyakan legalitas kebenaran analisis data yang digunakan 
oleh para peneliti sebelumnya dan pengembangan yang mungkin dilakukan untuk memperdalam penelitian tersebut agar memiliki nilai lebih sebagai tugas akhir.

\section{Kesimpulan}

Kegiatan pelatihan pengolahan data melalui program SPSS untuk meningkatkan kemampuan mahasiswa berjalan dengan lancar. Tujuan dilaksanakan kegiatan pengabdian masyarakat berupa pelatihan SPSS ini adalah untuk meningkatkan pemahaman peserta pelatihan mengenai penerapan program SPSS untuk mengolah data penelitian dalam menyusun tugas akhir. Semua peserta pelatihan antusias dan merasakan manfaat pelatihan ini.

\section{Daftar Pustaka}

Agung, Muhammad, Ivan. (2015). Modul Pelatihan SPSS.Pekanbaru: Fakultas Psikologi UIN Suska Riau.

Arikunto, S. (2010). Prosedur Penelitian: Suatu Pendekatan Praktik. (Edisi Revisi). Jakarta: Rineka Cipta

Azwar. (2010). Metode Penelitian. Yogyakarta: Penerbit Pustaka Pelajar.

Hartono. (2008). SPSS 16.0 Analisis Data Statistika dan Penelitian. Yogyakarta: Pustaka Pelajar.

PMPTK. (2008). Penulisan Modul. Jakarta.

LPM USI. (2020). Panduan Penulisan Pengabdian Masyarakat. USI Pematangsiantar.

Rochmad. (2011). Model Pengembangan Perangkat Pembelajaran Matematika. Makalah. Jurusan Matematika FMIPA UNNES.

Santiasa, I Wayan. (2009). Metode Penelitian Pengembangan dan Pengembangan Modul. Universitas Pendidikan Ganesha.

Sanjaya, Wina. (2008). Perencanaan dan Desain Sistem Penelitian. Jakarta: Kencana.

Sudjana. (2005). Metoda Statistika. Bandung: Tarsito.

Sugiyono. (2003). Statistika untuk Penelitian. Bandung: Alfabeta. 
Dedikasi Sains dan Teknologi

Jurnal Pengabdian Masyarakat

Vol: 1, No: 2, Nopember 2021

Doi : https://doi.org/10.47709/dst.v1i2.1068
Diajukan : 27 Agustus 2021

Accepted : 12 September 2021

Published : 6 Nopember 2021

\section{Lampiran-Lampiran}

1. Halaman Pengesahan

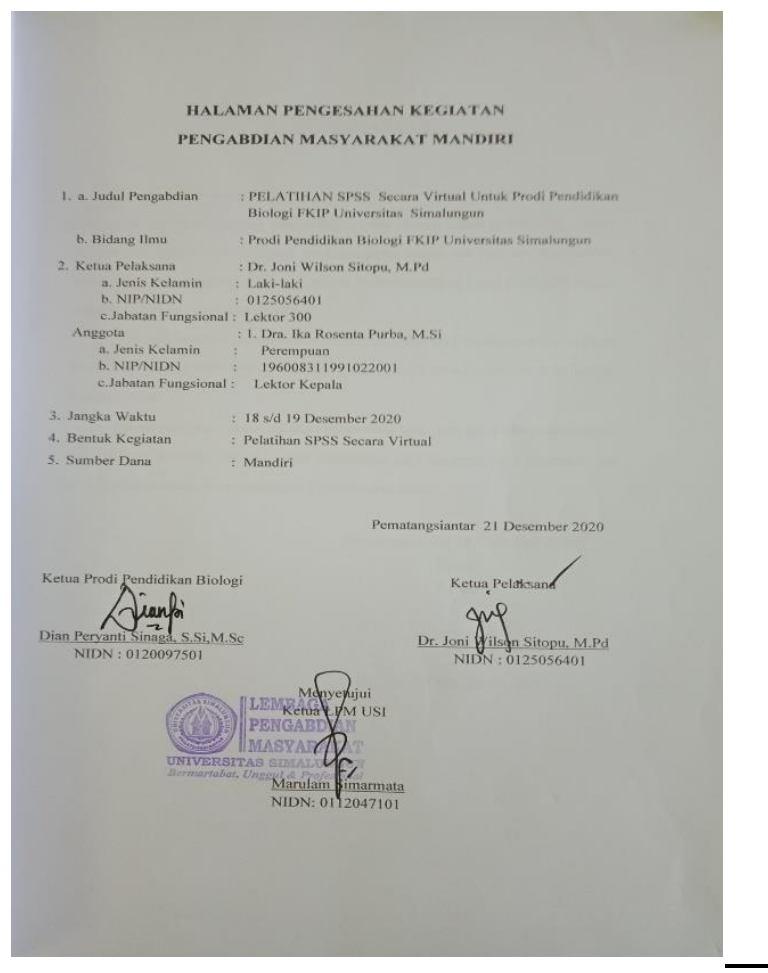

2. Surat Penugasan

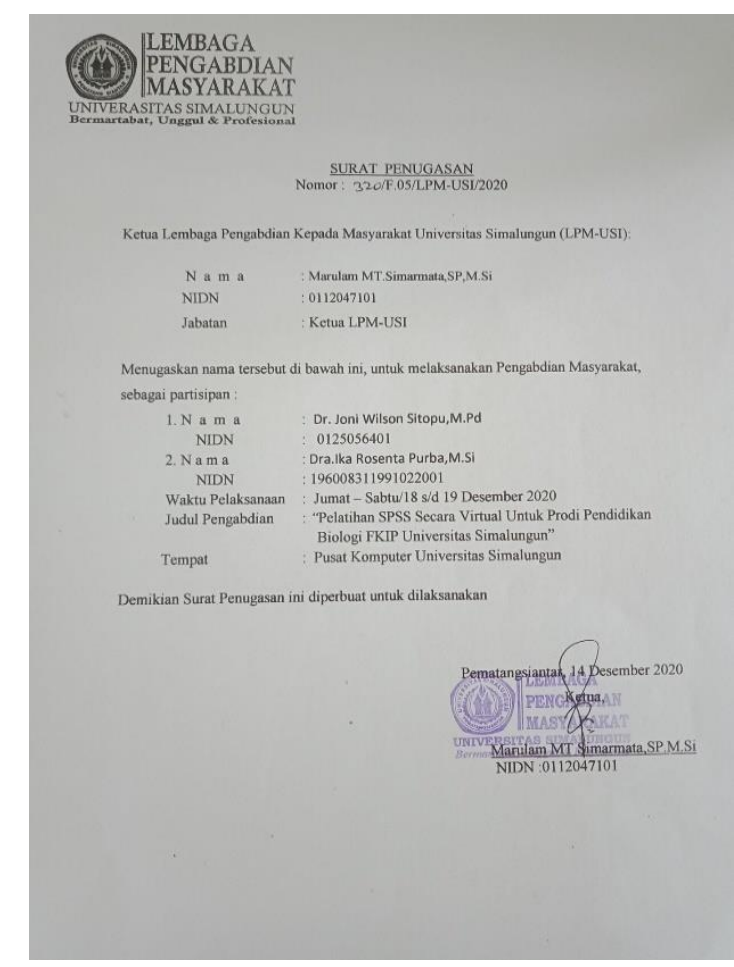

3. Absensi
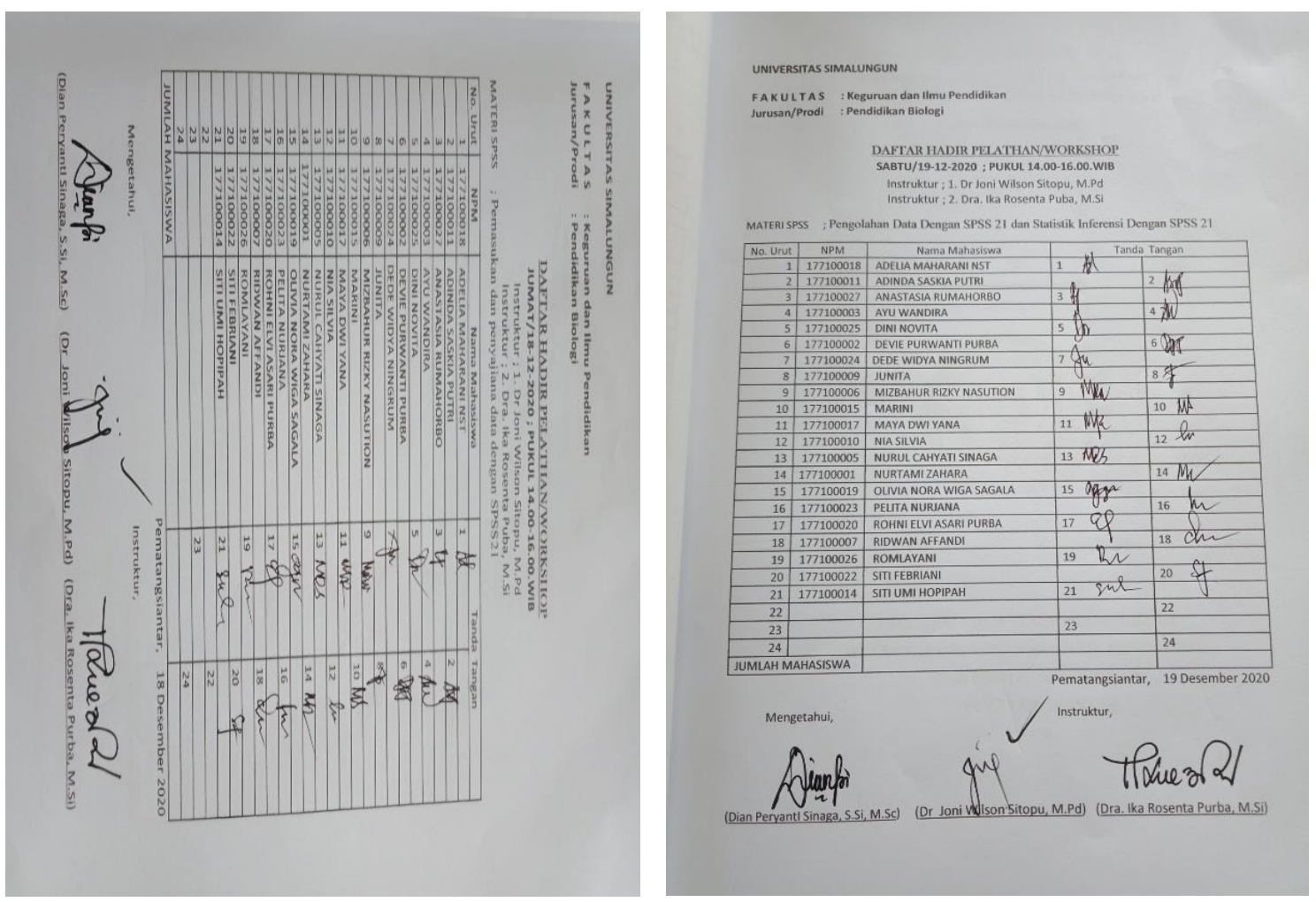
Dedikasi Sains dan Teknologi

Jurnal Pengabdian Masyarakat

Vol: 1, No: 2, Nopember 2021

Doi : https://doi.org/10.47709/dst.v1i2.1068
Diajukan : 27 Agustus 2021

Accepted : 12 September 2021

Published : 6 Nopember 2021

4. Dokumentasi Kegiatan

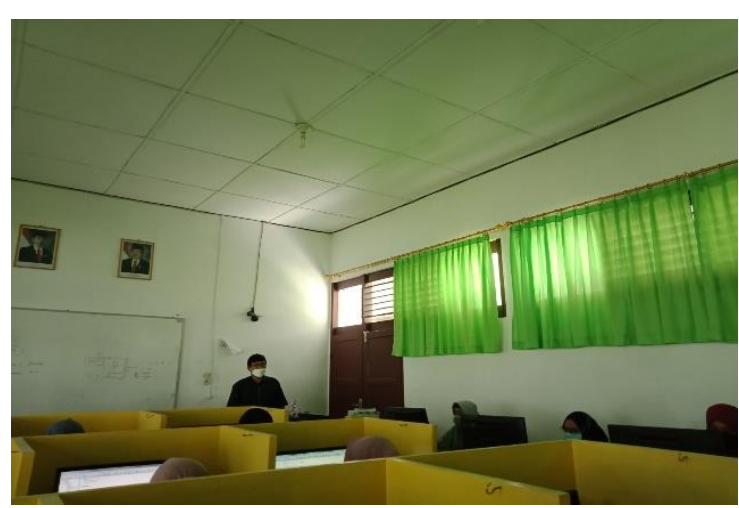

Tutorial

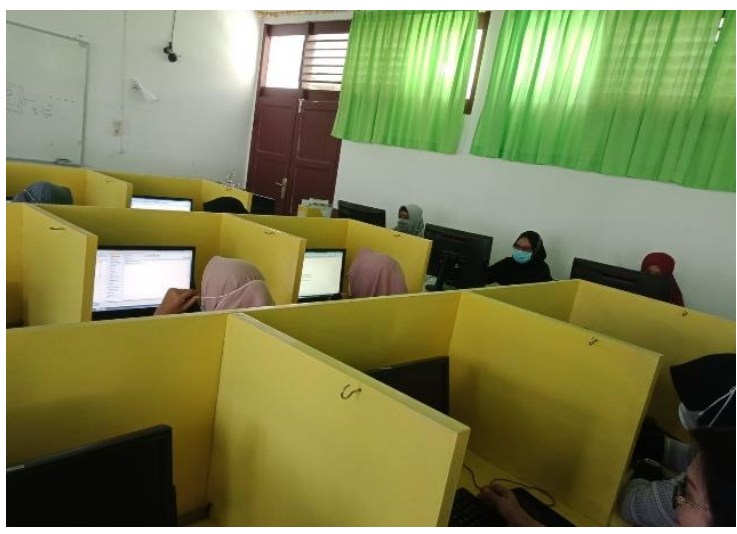

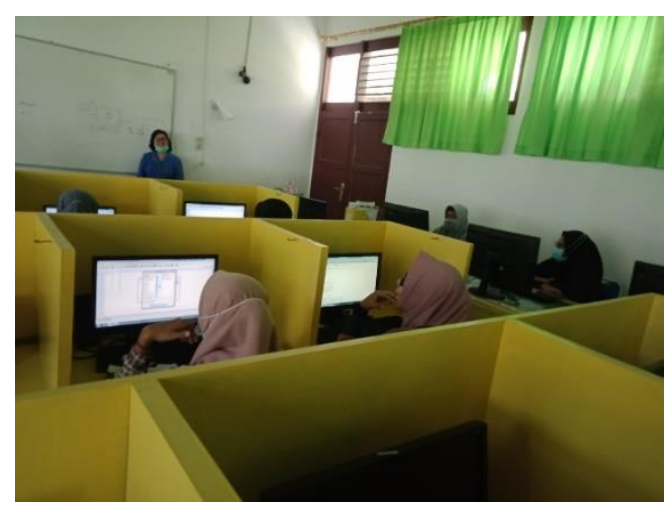

Workshop

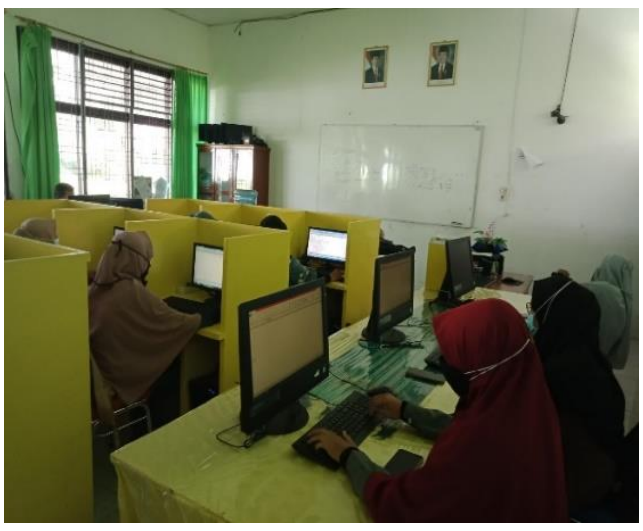

Simulasi 